\title{
Missing Links In Understanding The Relationship Between Leadership And Organizational Performance
}

Fenwick Feng Jing, Macquarie University, Australia

Gayle C. Avery, Macquarie University, Australia

\begin{abstract}
Both researchers and practitioners have devoted considerable attention to the potential effects of leadership on organizational performance. Despite increased research into the leadership-performance relationship, major gaps still remain in our understanding. This paper reviews the published literature and identifies these gaps, highlighting implications for future research into the leadership-performance relationship.
\end{abstract}

Keywords: leadership paradigms, organizational performance

\section{INTRODUCTION}

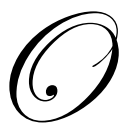

ver the last 25 years there has been considerable theoretical and empirical work conducted on organizational performance. This work has sought to better understand the antecedents, processes, and emergent states that facilitate effective organizational outcomes. An emerging area within this work is the role attributed to leadership in facilitating organizational performance enhancement. Over the past decades, the question of appropriate leadership paradigms and behaviours has received considerable attention from both researchers and managers. There has been an ongoing debate regarding the effects of leadership on organizational performance.

The purpose of this paper is to clarify the relationship between leadership paradigms and organizational performance based on the existing literature. It begins with reasons why the leadership-performance relationship is important, followed by a discussion of leadership paradigms and selected indicators for measuring them. It then discusses issues in measuring organizational performance, and concludes with a series of research propositions.

\section{IMPORTANCE OF THE LEADERSHIP-PERFORMANCE RELATIONSHIP}

During the past four decades, the impact of leadership styles on organizational performance has been a topic of interest among academics and practitioners working in the area of leadership (Cannella and Rowe, 1995; Giambatista, 2004; Rowe et al., 2005). Perhaps the most prominent reason for this interest is the widespread belief that leadership can affect the performance of organizations (Rowe et al., 2005). The style of leadership adopted is considered by some researchers (e.g. Awamleh, 1999; Conger, 1999; Dubinsky et al., 1995; Yammarino et al., 1993) to be particularly important in achieving organizational goals, and in evoking performance among subordinates (Barling et al., 1996; Berson et al., 2001; Zacharatos et al., 2000).

Despite the widespread acknowledgment of the importance and value of leadership, when studying the leadership literature, it is striking that the concept of leadership lacks coherence and agreement. Most of the leadership literature confuses the definition of effective leadership by failing to make clear distinctions in some 
definitions, such as between leaders and non-leaders, effective and ineffective leaders, as well as overlooking the definition of the levels of leadership (Bennis, 1998; Bergsteiner, 2005; House and Aditya, 1997). Further, there has been limited research that has specifically addressed the relationship between leadership behavior and organizational performance.

Despite these oversights, it is widely believed that leadership creates the vital link between organizational effectiveness and people's performance at an organizational level (Avolio, 1999; Bass, 1998; Judge, et al., 2002a, 2002c; Judge and Piccolo, 2004; Keller, 2006; McGrath and MacMillan, 2000; Purcell et al., 2004; Teece et al., 1997; Yukl, 2002). Substantial numbers of management scholars have debated the effectiveness of leadership styles and behaviors (Analoui, 1999; Avery, 2004; Drath, 2001; House and Aditya, 1997; Kakabadse et al., 1999; Shamir et al., 1993; Shamir and Howell, 1999; Yukl, 1999). The existing research leaves many unanswered questions and gaps.

In addition, much prior research has examined the assumed leadership-performance relationship, but it has examined a restricted number of leadership paradigms (e.g. visionary and transactional paradigms), while ignoring the potential role of other paradigms (e.g. classical and organic paradigms). Bernard Bass' (1985) distinction between transformational and transactional leadership is one such example. Scholars have criticised Bass's (1985) theory of transformational leadership, finding that there is no one best way of thinking about leadership, rather that different kinds of leadership reflect social and historical roots, depending on the context (Avery, 2004; Bryman, 1992; Drath, 2001; Shamir and Howell, 1999; Yukl, 1999).This implies that different leadership paradigms could affect performance differently, depending on the context. Thus, when researching the leadership-performance relationship, the context needs to be taken into account and more paradigms need to be considered.

Moreover, there are methodological problems with most existing studies. The majority of field studies have been cross-sectional in design, and the common-method bias often has been a problem when performance has been measured (Barling et al., 2002; Jermier and Kerr, 1997). The quality of performance measurement is critical to determining outcomes about whether leadership matters and not all studies have been well designed (Dionne et al., 2002). For example, when selecting measurements of performance, many researchers (e.g. Hofmann and Jones, 2005; Keller, 2006; Lim and Ployhart, 2004) neglected to focus on the correlation between financial performance and customer satisfaction and employee satisfaction, employing either financial measurements or non-financial measurements rather than employing all three in order to enhance the validity of the research. Therefore, closer attention is needed to ensuring that the measures of organizational performance are adequate and sufficient.

Research implications: No clear picture has emerged about the relationship between leadership and organizational performance. Despite increased research into the leadership-performance relationship, many problems and gaps remain in existing studies. There is a lack of integration concerning the relationship between leadership and performance, a narrow set of variables has been used in previous studies, and context and levels have been ignored. Therefore, there is a need for clarification.

\section{LINK BETWEEN LEADERSHIP AND ORGANIZATIONAL PERFORMANCE}

Several reasons indicate that there should be a relationship between leadership and performance. The first reason relates to practice. Today's intensive, dynamic markets feature innovation-based competition, price/performance rivalry, decreasing returns, and the creative destruction of existing competencies (Santora et al., 1999; Venkataraman, 1997). Scholars and practitioners suggest that effective leadership behaviors can facilitate the improvement of performance when organizations face these new challenges (McGrath and MacMillan, 2000; Teece, Pisano and Shuen, 1997).

Understanding the effects of leadership on performance is also important because leadership is viewed by some researchers (e.g. Zhu et al., 2005) as one of the key driving forces for improving a firm's performance. Effective leadership is seen as a potent source of management development and sustained competitive advantage for 
organizational performance improvement (Avolio, 1999; Lado et al., 1992; Rowe, 2001). For example, transactional leadership helps organizations achieve their current objectives more efficiently by linking job performance to valued rewards and by ensuring employees have the resources needed to get the job done (Zhu et al., 2005). Visionary leaders create a strategic vision of some future state, communicate that vision through framing and use of metaphor, model the vision by acting consistently, and build commitment towards the vision (Avolio, 1999; McShane and Von Glinow, 2000). Some scholars (e.g. Zhu et al., 2005) suggest that visionary leadership will result in high levels of cohesion, commitment, trust, motivation, and hence performance in the new organizational environments.

According to Mehra et al. (2006), when some organizations seek efficient ways to enable them to outperform others, a longstanding approach is to focus on the effects of leadership. This is because team leaders are believed to play a pivotal role in shaping collective norms, helping teams cope with their environments, and coordinating collective action. This leader-centred perspective has provided valuable insights into the relationship between leadership and team performance (Guzzo and Dickson, 1996).

Some researchers (e.g. Judge, et al., 2002b; Judge and Piccolo, 2004; Keller, 2006; McGrath and MacMillan, 2000; Meyer and Heppard, 2000; Purcell et al., 2004; Yukl, 2002) have started to explore the strategic role of leadership, and investigate how to employ leadership paradigms and use leadership behavior to improve organizational performance. The reason for this is because intangible assets such as leadership styles, culture, skill and competence, and motivation are seen increasingly as key sources of strength in those firms that can combine people and processes and organizational performance (Purcell et al., 2004, p.1). Previous research leads to the expectation that leadership paradigms will have direct effects on customer satisfaction, staff satisfaction, and financial performance.

However, in general, the effects of leadership on organizational performance have not been well studied, according to House and Aditya's review (1997). House and Aditya (1997) criticised leadership studies for focusing excessively on superior-subordinate relationships to the exclusion of several other functions that leaders perform, and to the exclusion of organizational and environmental variables that are crucial to mediate the leadership-performance relationship. A further problem with existing leadership research is that the results depend on the level of analysis. House and Aditya (1997) distinguished micro-level research that focuses on the leader in relation to his or her subordinates and immediate superiors, and macro-level research that focuses on the total organization and its environment. Other scholars also suggest that leaders and their leadership style influence both their subordinates and organizational outcomes (e.g. Tarabishy, et al., 2005).

Research implications: Despite a hypothesised leadership-performance relationship suggested by some researchers, current findings are inconclusive and difficult to interpret and inconclusive. Some scholars believe that leadership facilitates organizational performance enhancement, while others contradict this. Different concepts of leadership have been employed in different studies, making direct comparisons virtually impossible. Levels of leadership have not been distinguished. Gaps and unanswered questions remain. There is a need to re-examine the proposed leadership-performance relationship.

\section{LEADERSHIP TYPOLOGIES}

Several different categories of leadership paradigms have been suggested by various researchers. For example, Bass (1985) stated that there are four dimensions of transformational leadership, three dimensions of transactional leadership, and a nonleadership dimension of laissez-faire leadership (Bass, 1985). Avery (2004) suggested categorising leadership into four leadership paradigms, while Goleman (1995) prefers six leadership paradigms.

Despite Bass's (1985) model being acclaimed as making a major contribution to leadership, his theory has been criticised for various reasons (Yukl, 1999). One criticism is that his model overemphasises the importance of one or two leadership paradigms (e.g. transactional and visionary), omitting the classical and organic paradigms. 
Bass asserts that visionary (transformational) leaders are nearly always more effective than transactional leaders, but others (e.g. Judge and Piccolo, 2004; Wallace, 1997) dispute this. While this in itself does not invalidate the concept of visionary leadership, Bass attributes more to visionary (transformational) leadership than perhaps he should. As Avery (2004) suggested, both transactional and visionary leadership are valid forms of leadership, but visionary leadership may be applicable more broadly, including in situations where there are insufficient resources for the manager to rely on supplying external rewards (Judge and Piccolo, 2004), or where the situation is complex and ambiguous, and relies strongly on follower knowledge and commitment. Avery suggests that there are other situations in which transactional leadership is the appropriate form of leadership, such as when followers are unwilling or unable to commit to the leader's vision.

In contrast with Bass's (1985) model, Avery's (2004) paradigms provide a broad basis allowing for different forms of leadership that have evolved at different times and in different places. The paradigms are useful for showing that there is no single best way of thinking about leadership, rather that different kinds of leadership reflect social and historical roots. Avery's paradigms allow leadership to depend on the context, respond to organizational needs and preferences, and involve many interdependent factors that can be manipulated (Bryman, 1992; Shamir and Howell, 1999; Yukl, 1999).

Research implication: Avery's typology of four kinds of leadership paradigms can be adopted as a framework for measuring concepts of leadership because it covers a broad range of leadership concepts.

\section{LEADERSHIP PARADIGMS AND MEASURES}

Avery (2004) proposes 13 indices to differentiate between her four paradigms: classical, transactional, visionary, and organic. The nine indices included in this review are decision making, range of staff's power, power distance between leader and the staff, key player of the organization, source of staff's commitment, staff's responsibility, situation of management and leadership in the organization, situation of diversity in the organization and situation of control in the organization. These nine criteria are considered more relevant for differentiating the four leadership paradigms than the other four criteria. Each paradigm is discussed in turn, including the distinguishing characteristics using the above nine criteria.

Classical leadership is probably the oldest paradigm with its origins in antiquity, and is still used in contemporary organizations (Avery, 2004). This paradigm reflected the prevailing view in the business literature until the 1970s when the human relations movement led to more of a focus on followers and their environment. According to Avery (2004), classical leadership refers to dominance by a pre-eminent person or an 'elite' group of people. This leadership can either be coercive or benevolent or a mixture of both. This happens because the elite individual or group commands or manoeuvres other members to act towards a goal, which may or may not be explicitly stated. The other members of the society or organisation typically adhere to the directives of the elite leader, do not openly question their directives, and execute orders largely out of fear of the consequences of not doing so, or out of respect for the leader, or both (Avery, 2004).

Classical leadership has some limitations. The first occurs where the leader cannot command and control every action, particularly as situations become more complex and beyond the capacity of one person; or when additional commitment from followers is needed to get a job done, such as in reacting to changing circumstances; or when ideas about leadership change and followers no longer accept domination, or follower commitment starts to wane for other reasons. Another limitation is that this paradigm often relies on the idea of a 'great person', implying that only a select few are good enough to exercise initiative, and this belief can encourage followers to deskill themselves and idealize the leaders. Followers then seek and hold little power, leave the leader accountable for organizational outcomes, and make relatively little contribution to the organization (Avery, 2004).

According to the nine distinguishing indicators, under the classical leadership paradigm leaders normally use an autocratic style for making decisions, involving followers in the decision making process never or very little; 
they do not empower followers. Followers have almost no power in the organization and as classical leaders tend to be highly directive, followers can be unskilled. The source of followers' commitment comes from their fear of or respect for the leaders; the technical system becomes more regulating; the operations in the organization become more routine and predictable; and the organization is highly controlled by the leaders (Avery, 2004).

A transaction or exchange process is the basis of the commonly employed transactional leadership paradigm (Evans and Dermer, 1974; House and Mitchell, 1974). The transactional leader recognises subordinates' needs and desires, and then clarifies how those needs and desires will be met in exchange for subordinates' work. By clarifying what is required of subordinates and the consequences of their behaviors, transactional leaders are able to build confidence in subordinates to exert the necessary effort to achieve expected levels of performance.

According to Judge and Piccolo (2004), three dimensions of transactional leadership are contingent reward, management by exception-active, and management by exception-passive. Contingent reward is the degree to which the leader sets up constructive transactions or exchanges with followers. The leader clarifies expectations and establishes the rewards for meeting these expectations. In general, management by exception is the degree to which the leader takes corrective action on the basis of results of leader-follower transactions (Judge and Piccolo, 2004). As noted by Howell and Avolio (1993), the difference between management by exception-active and management by exception-passive lies in the timing of the leader's intervention. Active leaders monitor follower behavior, anticipate problems, and take corrective actions before the behavior creates serious difficulties. Passive leaders wait until the behavior has created problems before taking action (Howell and Avolio, 1993; Judge and Piccolo, 2004).

According to Avery (2004, p.34), under the transactional leadership paradigm, leaders adopt a consultative style for making decisions. They engage in different degrees of consultation with individual followers, but the leaders remain the final decision-makers. Leaders do not very often empower followers, and followers have very low power in the organization apart from being able to withdraw from or contribute more of their labor. Compared with classical leadership, under transactional leadership the source of followers' commitment comes from the rewards, agreements, and expectations negotiated with the leader rather than from their fear of, or respect for, the classical leader. The technical system becomes more regulating, the operations in the organization become more routine and predictable, and the organization is mostly highly controlled by the leaders. Avery (2004) argues that under transactional leadership, the followers' knowledge base can be somewhat higher than under classical leadership. Compared with classical leaders, transactional leaders require staff somewhat more skilled on specific tasks.

In the last three decades, visionary (transformational, charismatic) leadership has received increasing attention (Bass,1985, 1998; Burns, 1978; Conger and Kanungo, 1987; House, 1977). It added a new dimension to organizational studies, namely the visionary aspect of leadership and the emotional involvement of employees within an organization. The basic notion is that a visionary leader can create an impression that he or she has high competence and a vision to achieve success. Subordinates are expected to respond with enthusiasm and commitment to the leadership objectives, and may be recruited because they share the vision. Bass $(1985,1998)$ developed a theory of visionary or transformational leadership whereby the leader inspires and activates subordinates to perform beyond normal expectations.

According to Avery (2004), visionary leadership has limitations, even with the current literature's overwhelmingly positive view of it. Nadler and Tuschman (1990) pointed out that the unrealistic expectations followers often place on visionary leaders can create disappointment if things do not work out. Followers can become dependent on visionary leaders, believing that the leader has everything under control. Also, innovation can be inhibited if people become reluctant to disagree with a visionary leader.

Avery $(2004$, p.39) distinguishes the visionary leadership paradigm from the other three paradigms as follows. First, leaders employ a collaborative style for making decisions. They share problems with their followers and seek consensus before the leaders make the final decision. Visionary leaders empower their followers, giving 
followers a much higher level of power in the organization than classical and transactional leadership. This is essential because the leader needs the followers' input and commitment to realise his or her goals. Followers of visionary leadership need sufficient power to work autonomously towards a shared vision. The source of followers' commitment comes from the influence of the leaders' charisma and/or the shared vision, the technical system becomes still more complex, operations become more uncertain and unpredictable, and the organization is jointly controlled by the leaders and their followers. Regarding the followers' knowledge base, visionary leadership requires skilled and knowledgeable workers who are attracted to, and share the leader's vision, and can contribute to realizing the vision.

The fourth paradigm, organic leadership, is relatively new to organizational studies. Recently introduced by Drath (2001) and expanded by Avery (2004), organic leadership is likely to blur the formal distinction between leaders and followers. This paradigm relies on reciprocal actions, where team members work together in whatever roles of authority and power they may have, not based on position power (Hirschhorn, 1997; Raelin, 2003; Rothschild and Whitt, 1986). Employees become interacting partners in determining what makes sense, how to adapt to change, and what is a useful direction. Rather than relying on one leader, organic organizations are likely to have many leaders. Multiple leaders are valuable because as people cope with heterogeneous and dynamic environments, the knowledge and issues become too complicated for only a few leaders to understand (Avery, 2004). Organic leadership allows for people with different degrees of expertise on current issues to emerge and be accepted by the group as leaders.

In addition, under organic leadership, there may be no formal leaders and the interaction of all organizational members can act as a form of leadership, held together by a shared vision, values, and a supporting culture. Under this paradigm where an organization has no formal leadership structure, an integrator role may emerge to actively link together the many parts of the organisation (Avery, 2004). The emphasis is on emerging leadership rather than on people being appointed to leadership positions.

However, Kanter (1989) argued that the downside of organic leadership that advocates autonomy, freedom, discretion and authorization may result in loss of control and greatly increased uncertainty. It is important to recognise that organic leadership is about generating a form of self-control and self-organization, where people have a clear sense of purpose and autonomy within a particular context (Meindl, 1998). This idealized organic leadership paradigm requires differentiating from classical, transactional, and visionary leadership concepts by not relying on formal leaders. Furthermore, the enterprise has to trust in the capacity of its members to solve problems and make decisions in the interests of the organization. This idea clearly relies upon self-leading organizational members (Avery, 2004).

According to Avery's (2004, p. 39) distinguishing characteristics, under organic leadership an organisation adopts a mutual agreement style for making decisions. Decisions need not be unanimous but can be based on consensus. The members have a high degree of power as a result of this shared leadership. Accountability and responsibility are shared as well. The source of followers' commitment is based on the values and visions shared by all the members in the organization; a strong, shared culture; a technical system that is highly complex; operations in the organic organization become more self-organizing and unpredictable; formal control is provided by peer pressure and group dynamics, and a shared culture, vision, and values. Members are self-managing. Organic leadership seems particularly appropriate for professional and knowledge workers in dynamic, chaotic situations. This leadership paradigm relies on attracting and retaining highly trained and knowledgeable staff with self-controlling capabilities.

Research implications: Nine indicators distinguish the leadership paradigms, namely decision making, range of staff's power, power distance between leader and the staff, key player of the organization, source of staff's commitment, staff's responsibility, situation of management and leadership in the organization, situation of diversity in the organization and situation of control in the organization. These are considered important and appropriate measures of the leadership paradigms. 


\section{PERFORMANCE MEASURES}

How to measure organizational performance has been a persistent source of debate and critique (Scherbaum et al., 2006). Previous research has been heavily criticized for the measures of performance used. For example, Hoogh et al. (2004) criticized the selection of performance measures in most existing leadership-performance research for their limited perspective, and focus on only a few subjective outcome measures. Knowledge of prior performance may have biased ratings of leader behavior and performance (Binning et al., 1986); and the most used criterion measures for assessing the effects of leadership behavior rely on followers' self-reports of commitment to the organization's goals, satisfaction with the leader, and perceived leader effectiveness (Hoogh $e t$ al., 2004). This can induce common-method bias, such as central tendency, social desirability, and halo effects (e.g. Bass and Avolio, 1989). However, some scholars (i.e. Crampton and Wagner, 1994; Hoogh et al., 2004) argue that not all studies are biased by such self-report effects, and meta-analytic findings suggest that self-report is still reliable to use if the potential weaknesses are overcome.

Several studies have used nonself-report based organizational outcomes, such as net profit margin (Koene et al., 2002; Waldman et al., 2001), business unit sales (e.g. Barling et al., 1996; Hoogh et al., 2004), and percentage of goals met regarding business-unit performance (Hoogh et al., 2004; Howell and Avolio, 1993). While reducing common-source and common-method bias, these measures of organizational performance have been criticized for being overly narrow (Bommer et al., 1995; Hoogh et al., 2004), thus suffering from criterion deficiency. The situation is even more complicated because the relationship between leadership behavior and organizational outcome measures is often quite indirect (Den Hartog et al., 1997; Hoogh et al., 2004). Measures of organizational performance are heavily dependent upon environmental constraints and may reflect forces outside the control of the leader, thus suffering from criterion contamination (Heneman, 1986; Hoogh et al., 2004)

Considering the limitations of each type of criterion and the multidimensional nature of performance, the use of multiple performance indicators obtained through different methods seems desirable in leadership-performance research. Comparison of the relationships found with different performance outcomes may reveal information about the magnitude of possible measurement biases, while providing a more accurate estimate of the 'true' relationship between leadership styles and organizational performance (Hoogh et al., 2004; Lowe et al., 1996).

Furthermore, when selecting performance measurements, many scholars (e.g. Hofmann and Jones, 2005; Keller, 2006; Lim and Ployhart, 2004) neglected to focus on the correlation between financial performance, customer satisfaction and employee satisfaction. They employed either financial measurements (i.e. net profits and controllable costs) or non-financial measurements (i.e. customer satisfaction and employee satisfaction), rather than employing both in order to enhance the validity of the research. This would result in inadequate and insufficient performance measurements of the proposed leadership-performance relationship. The disadvantage of selecting these measurements selection would include using inadequate measures to properly evaluate the relationship between leadership paradigms and performance.

Numerous empirical studies show a strong positive relationship between employee satisfaction, customer satisfaction, and organizational performance as measured by employee's and customer's self-reports to assess the effects of leadership behavior (e.g. Band, 1988; George, 1990; Johnson, 1996; Reynierse and Harker, 1992; Schmitt and Allscheid, 1995; Schneider and Bowen, 1985; Schneider et al., 1996; Schneider et al., 1998; Ulrich et al., 1991; Wiley, 1991). As suggested by this wealth of findings, positive changes in employee satisfaction and customer satisfaction lead to positive changes in organizational performance. Therefore, employee satisfaction and customer satisfaction remain useful measures of organizational performance.

In sum, based on the above discussion, the quality of performance measurement is critical to determining outcomes about whether leadership matters, although not all studies have been well designed in this respect. 
Research implications: Methodological problems limit most existing studies. Multiple performance measurement criteria should be used. In addition to financial measures (i.e. net profits and sales turnover), non-financial measures (i.e. staff satisfaction and customer satisfaction) should be used to provide a more robust picture of organizational performance than previous studies.

\section{CONCLUSIONS AND RESEARCH IMPLICATIONS}

Although the definition of leadership is contentious, many practitioners and scholars argue that leadership creates the vital link between organizational effectiveness and people's performance at an organizational level. Many writers assert that leadership behaviors can facilitate the improvement of both leaders' leadership capability and induce or encourage employees to work better improve their commitment and satisfaction. This ultimately contributes to enhancing organizational performance.

However, research into the leadership-performance relationship is not conclusive. Many scholars have critically examined the effectiveness of leadership paradigms and behaviors (Analoui, 1999; Avery, 2004; Drath, 2001; House and Aditya, 1997; Kakabadse et al., 1999; Shamir et al. 1993; Shamir and Howell, 1999; Yukl, 1999). They conclude that existing research on the leadership-performance relationship is full of difficulties and has many unsolved problems, including methodological problems. Thus, conclusions cannot be drawn about the extent to which leadership behaviors and styles facilitate the improvement of organizational performance. This literature review highlights some of the problems and gaps in existing research, which are discussed and summarised in the following paragraphs.

One problem relates to the quality of performance measurement. When selecting the measurements of performance, previous researchers have employed either financial measurements or non-financial measurements, rather than employing both kinds of measures in order to enhance the validity of the research. They have neglected the interrelationship between financial performance and customer satisfaction and employee satisfaction. This provides a narrow measurement of performance that may not have appropriately evaluated the sought-after performance effects appropriately. Thus, both financial measurements and non-financial measurements of performance are essential in order to enhance research validity.

Additionally, previous scholars (e.g. Bass, 1985) have focused on a limited range of leadership paradigms (e.g. transactional and visionary). Classical and organic paradigms have been omitted when researching the leadership-performance relationship. This truncates leadership measurements. While Bass has claimed that visionary leadership is almost always more effective than transactional leadership, other researchers (e.g. Avery, 2004) argue that there is no single leadership paradigm that is the most effective. Instead, an organization should adopt the leadership style that suits the context in which the leadership and followers interact. Therefore, future research should be extended by encompassing a broad conceptualisation of leadership such as that offered by Avery's (2004) four leadership paradigms. This broadens the scope of the leadership perspectives and measures.

Moreover, most previous empirical studies into the effects of leadership on performance (Lim and Ployhart, 2004) have been directed toward individual-level outcomes, such as individual satisfaction and performance. Little attention has been paid to the influence of a leader on group or organizational processes and outcomes (Conger, 1999; Yukl, 1999). Yukl (2002) points out that the visionary leadership literature has focused too narrowly on dyadic processes, and calls for greater attention to team-based studies. Both of these issues represent additional gaps in the existing research.

Furthermore, even where previous studies have examined the link between leadership paradigms and behaviors and have shown a positive relationship, none has explained the nature of this connection, and therefore, how and why leadership affects performance. Future research needs to address this deficiency.

In sum, based on the above discussion, there are many problems and gaps in existing studies of the 
leadership-performance relationship that need to be addressed before a clear picture of this relationship can be drawn.

\section{AUTHOR INFORMATION}

Fenwick Feng Jing is a Doctor of Business Administration student within the Institute for Sustainable Leadership at Macquarie Graduate School of Management, Macquarie University, Australia. He holds a BA from Shandong Normal University, China and an MSc from Lancaster University, UK. He currently researches leadership and organizational performance. Previously, he served as a governmental official in China and management consultant in Shanghai, specializing in human resource services and designing management development programs for executives in different organizations.

Professor Gayle C. Avery specializes in leadership and management development at Macquarie Graduate School of Management, Macquarie University, Sydney, where she is founding head of the Institute for Sustainable Leadership. Author of many books and articles, she actively researches leadership from a global perspective. She remains in touch with practicing managers as consultant, and by designing and delivering leadership courses for a range of senior executives from multinational corporations based in Asia, Europe and Australia.

\section{REFERENCES}

1. Analoui, F. (1999) Eight parameters of managerial effectiveness. Journal of Management Development, 18(4):362-389.

2. $\quad$ Avery, G.C. (2004) Understanding Leadership: Paradigms and Cases. London: Sage.

3. Avolio, B.J. (1999) Full Leadership Development: Building the Vital Forces in Organizations. Thousand Oaks, CA: Sage.

4. Awamleh, R. and Gardner, W.L. (1999) Perceptions of leader charisma \& effectiveness: The effects of vision content, delivery \& organizational performance. The Leadership Quarterly, 10: 345-373.

5. Band, W. (1988) Customer-satisfaction studies changing marketing strategies. Marketing News, 22:14.

6. Barling, J., Loughlin, C. and Kelloway, E.K. (2002) Development \& test a model linking safety-specific transformational leadership \& occupational safety. Journal of Applied Psychology, 87(3): 488-496.

7. Barling, J., Weber, T. and Kelloway, E.K. (1996) Effects of transformational leadership training on attitudinal \& financial outcomes: A field experiment. Journal of Applied Psychology, 81(6): 827-832.

8. $\quad$ Bass, B.M. (1985) Leadership \& Performance Beyond Expectations. New York, NY: Free Press.

9. Bass, B.M. (1998) Transformational Leadership: Industry, Military \& Educational Impact. Mahwah, NJ: Erlbaum.

10. Bass, B.M. and Avolio, B.J. (1989) Potential biases in leadership measures: How prototypes, leniency, \& general satisfaction relate to ratings \& rankings of transformational \& transactional leadership constructs. Educational \& Psychological Measurement, 49: 509-527.

11. Bennis, W. (1998) Rethinking leadership. Executive Excellence, 15(2):7-8.

12. Bergsteiner, H. (2005) Bergsteiner's Leadership Matrix. Unpublished Paper, MGSM, Australia.

13. Berson, Y., Shamair, B., Avolio, B.J. and Popper, M. (2001) The relationship between vision strength, leadership style \& context. The Leadership Quarterly, 12: 53-73.

14. Binning, J.F., Zaba, A.J. and Whattam, J.C. (1986) Explaining the biasing effects of performance cues in terms of cognitive categorization. The Academy of Management Journal, 29(3): 521-535.

15. Bommer, W.H., Johnson, J.L., Rich, G.A., Podsakoff, P.M. and MacKenzie, S.B. (1995) On the interchangeability of objective $\&$ subjective measures of employee performance: A meta-analysis. Personnel Psychology, 48 (3), 587-605.

16. Bryman, A. (1992) Charisma \& Leadership in Organizations. London: Sage.

17. Burns, J.M. (1978) Leadership. New York, NY: Harper and Row.

18. Cannella Jr., A.A. and Rowe, W.G.. (1995) Leader capabilities, succession \& competitive context: A baseball study. The Leadership Quarterly, 1: 69-88. 
19. Conger, J.A. (1999) Charismatic \& transformational leadership in organizations: An insider's perspective on these developing streams of research. The Leadership Quarterly, 10(2): 45-169.

20. Conger, J.A. and Kanungo, R.N. (1987) Toward a behavioral theory of charismatic leadership in organizational settings. Academy of Management Review, 12(4):637-647.

21. Crampton, S.M. and Wagner, J.A. (1994) Percept-percept inflation in microorganizational research: An investigation of prevalence \& effect. Journal of Applied Psychology, 79(1): 67-76.

22. Den Hartog, DN, Van Muijen, J.J. and Koopman, P.L. (1997) Transactional versus transformational leadership: An analysis of the MLQ. Journal of Occupational \& Organizational Psychology, 70: 19-34.

23. Dionne, S.D., Yammarino, F.J., Atwater, L.E., James, L.R. (2002) Neutralizing substitutes for leadership theory: Leadership effects \& common-sourve bias. Journal of Applied Psychology, 87(3): 454-464.

24. Drath, W.H. (2001) The Deep Blue Sea: Rethinking the Source of Leadership. San Francisco, CA: Jossey-Bass.

25. Dubinsky, A.J., Yammarino, F.J., Jolson, M.A. and Spangler, W.D. (1995) Transformational leadership: An initial investigation in sales management. Journal of Personal Selling \& Sales Management, 15: 17-31.

26. Evans, M.G. and Dermer, J. (1974) What does the least preferred co-worker scale really measure? A cognitive interpretation. Journal of Applied Psychology, 59(2): 202-206.

27. George, W.R. (1990) Internal marketing \& organizational behavior: A partnership in developing customer-conscious employees at every level. Journal of Business Research, 20 (1): 63-70.

28. Giambatista, R.C. (2004) Jumping through hoops: A longitudinal study of leader life cycle in the NBA. The Leadership Quarterly, 15: 607-624.

29. Goleman, D.P. (1995) Emotional Intelligence: Why It Can Matter More Than IQfor Character, Health \& Lifelong Achievement. New York, NY: Bantam.

30. Guzzo, R.A. and Dickson, M.W. (1996) Teams in organizations: Recent research on performance \& effectiveness. Annual Review of Psychology, 47(1):307-338.

31. Heneman, R.L. (1986) The relationship between supervisory ratings \& results-oriented measures of performance: A meta-analysis. Personnel Psychology, 39:811-826.

32. Hirschhorn, L. (1997) Reworking Authority: Leading and Following in the Post-Modern Organization. Cambridge, MA: MIT Press.

33. Hofmann, D.A. and Jones, L.M. (2005) Leadership, collective personality \& performance. Journal of Applied Psychology, 90(3): 509-522.

34. Hoogh, A.H.B. de, Hartog, D.N. den, Koopman, P.L., Berg, H.T., Berg, P.T. van den, Weide, J.G. van der and Wilderom, C.P.M. (2004) Charismatic leadership, environmental dynamism \& performance. European Journal of Work and Organizational Psychology, 13(4): 447-471.

35. House, R.J. (1977) A 1976 theory of charismatic leadership, in J.G. Hunt and L.L. Larson (eds), Leadership: The cutting edge. Carbondale, IL: Southern Illinois Press.

36. House, R.J. and Aditya, R.N. (1997) The social scientific study of leadership: Quo Vadis? Journal of Management, (23)3: 409-473.

37. House, R.J. and Mitchell, T.R. (1974) Path-goal theory of leadership. Contemporary Business, 3(4): 81-98.

38. Howell, J.M. and Avolio, B.J. (1993) Transformational leadership, transactional leadership, locus of control \& support for innovation: Key predictors of consolidated-business-unit performance. Journal of Applied Psychology, 78(6): 891-902.

39. Jermier, J.M. and Kerr, S. (1997) Substitutes for leadership: Their meaning \& measurement. The Leadership Quarterly, 8 (2): 95-101.

40. Johnson, J.W. (1996) Linking employee perceptions of service climate to customer satisfaction. Personnel Psychology, 49: 831-851.

41. Judge, T.A., Bono, J.E., Ilies, R. and Gerhardt, M.W. (2002) Personality \& leadership: A qualitative \& quantitative review. Journal of Applied Psychology, 87(4): 765-780.

42. Judge, T.A., Heller, D. and Mount, M.K. (2002) Five-factor model of personality \& job satisfaction: A meta-analysis. Journal of Applied Psychology, 87(3): 530-541.

43. Judge, T.A. and Ilies, R. (2002) Relationship of personality to performance motivation: A meta-analytic review. Journal of Applied Psychology, 87(4): 797-807. 
44. Judge, T.A. and Piccolo, R.F. (2004) Transformational \& transactional leadership: A meta-analytic test of their relative validity. Journal of Applied Psychology, 89(5): 755-768.

45. Kakabadse, A. and Kakabadse, N. (1999) Essence of Leadership (Global Manager). London: Thomson Learning.

46. $\quad$ Kanter, R. (1989) When Giants Learn to Dance. New York, NY: Simon and Schuster.

47. Keller, R.T. (2006) Transformational leadership, initiating structure \& substitutes for leadership: A longitudinal study of research \& development project team performance. Journal of Applied Psychology, 91(1): 202-210.

48. Koene, B.A.S.; Vogelaar, A.L.W. and Soeters, J.L. (2002) Leadership effects on organizational climate \& financial performance: Local leadership effect in chian organizations. The leadership Quarterly, 13: 193-215.

49. Lado, A.A., Boyd, N.G. and Wright, P. (1992) A competency-based model of sustainable competitive advantage: Toward a conceptual integration. Journal of Management, 18(1): 77-91.

50. Lim, B. and Ployhart, R.E. (2004) Transformational leadership: Relations to the five-factor model $\&$ team performance in typical and maximum contexts. Journal of Applied Psychology, 89(4): 610-621.

51. Lowe, K.B., Kroeck, K.G. and Sivasubramaniam, N. (1996) Effectiveness of correlates of transformational \& transactional leadership: A meta-analytic review of the MLQ literature. Leadership Quarterly, 7: 385-425.

52. McGrath, G.R and MacMillan, I.C. (2000) Entrepreneurial Mindset: Strategies for Continuously Creating Opportunity in an Age of Uncertainty. Harvard Business School Press Books.

53. McShane, S.L. and Von Glinow, M.A. (2000) Organizational Behavior. Burr Ridge, IL: Irwin/McGraw-Hill.

54. Mehra, A., Smith, B.R., Dixon, A.L. and Robertson, B. (2006) Distributed leadership in teams: The networks of leadership perceptions \& team performance. The Leadership Quarterly, 17(3): 232-245.

55. Meindl, J.R. (1998) Invited Reaction: Enabling visionary leadership. Human Resource Development Quarterly, 9(1): 21-24.

56. Meyer, G.D. and Heppard, K.A. (2000) Entrepreneurial Strategies: The Dominant Logic of Entrepreneurship. New York, NY: Irwin University Books.

57. Nadler, D.A. and Tuschman, M.L. (1990) Beyond the charismatic leader: Leadership \& organizational change. California Management Review, 32(2): 77-97.

58. Purcell, J., Kinnie, N., Hutchinson, S., Rayton, B. and Swart, J. (2004) Understanding the People \& Performance Link: Unlocking the Black Box. Research Report, Chartered Institute of Personnel and Development.

59. Raelin, J. (2003) Creating Leadership Organizations: How to Bring out Leadership in Everyone. San Francisco, CA: Berrett-Koehler.

60. Reynierse, J.H. and Harker, J.B. (1992) Employee \& customer perceptions of service in banks: Teller \& customer service representative ratings. Human Resource Planning, 15: 31-46.

61. Rothschild, J. and Whitt, J.A. (1986) The Cooperative Work Place: Potentials \& Dilemmas of Organizational Democracy \& Participation. Cambridge: Cambridge University Press.

62. Rowe, W.G. (2001) Creating wealth in organizations: The role of strategic leadership. Academy of Management Executive, 15: 81-94.

63. Rowe, W.G., Cannella Jr., A.A., Rankin, D. and Gorman, D. (2005) Leader succession \& organizational performance: Integrating the common-sense, ritual scapegoating \& vicious-circle succession theories. The leadership Quarterly, 16(2):197-219.

64. Santora, J.C., Seaton, W. and Sarros, J.C. (1999) Changing times: Entrepreneurial leadership in a community-based nonprofit organization. Journal of Leadership Studies, 6(3-4): 101-109.

65. Schmit, M.J. and Allscheid, S.P. (1995) Employee attitudes \& customer satisfaction: Making a theoretical \& empirical connection. Personnel Psychology, 48: 521-537.

66. Schneider, B., Ashworth, S., Higgs, C. and Carr, L. (1996) Design, validity \& use of strategically focused employee attitude surveys. Personnel Psychology, 49:695-705. 
67. Schneider, B. and Bowen, D.E. (1985) Employee \& customer perceptions of service in banks: Replication \& extension. Journal of Applied Psychology, 7(3): 423-33.

68. Schneider, B., White, S. and Paul, M. (1998) Linking service climate \& customer perceptions of service quality: Test of a causal model. Journal of Applied Psychology, 83:150-163.

69. Schriesheim, C.A., Castro, S.L., Zhou, X. and Dechurch, L.A. (2006) An investigation of path-goal \& transformational leadership theory predications at the individual level of analysis. The Leadership Quarterly, 17(1): 21-38.

70. Shamir, B., House, R.J. and Arthur, M.B. (1993) The motivational effects of charismatic leadership: A self-concept based theory. Organization Science, 4(4): 577-594.

71. Shamir, B. and Howell, J.M. (1999) Organizational \& contextual influences on the emergence \& effectiveness of charismatic leadership. The Leadership Quarterly, 10(2): 257-283.

72. Tarabishy, A., Solomon, G., Fernald Jr., L.W. and Sashkin, M. (2005) The Entrepreneurial leader's impact on the organization's performance in dynamic markets. Journal of Private Equity, 8(4): 20-29.

73. Teece, D.J., Pisano, G. and Shuen, A. (1997) Dynamic capabilities \& strategic management. Strategic Management Journal, 18(7): 509-533.

74. Ulrich, D., Halbrook, R., Meder, D., Stuchlik, M. and Thorpe, S. (1991) Employee \& customer attachment: Synergies for competitive advantage. Human Resource Planning, 14: 89-103.

75. Venkataraman, S. (1997) The distinctive domain of entrepreneurship research: An editor's perspective, in J.Katz and J. Brodkhaus (eds), Advances in Entrepreneurship, Firm Emergence, and Growth. Greenwich, CT: JAI, Press, 3: 19-38.

76. Waldman, D., Ramirez, G., House, R.J. and Puranam, P. (2001) Does leadership matter? CEO leadership attributes \& profitability under conditions of perceived environmental uncertainty. Academy of Management Journal, 44(1): 134-143.

77. Wallace, J.E. (1997) Becker's side-bet theory of commitment revisited: Is it time for a moratorium or a resurrection? Human Relations, 50(6): 727-749.

78. Wiley, J.W. (1991) Customer satisfaction: A supportive work environment \& its financial cost. Human Resource Planning, 14:117-127.

79. Yammarino, F.J., Spangler, W.D. and Bass, B.M. (1993) Transformational leadership \& performance: A longitudinal investigation. The Leadership Quarterly, 4(1): 81-102.

80. Yukl, G. (1999) An evaluative essay on current conceptions of effective leadership. European Journal of Work \& Organizational Psychology, 8(1): 33-48.

81. Yukl, G. (2002) Leadership in organizations. 5 rd edn. Englewood Cliffs, NJ: Prentice-Hall.

82. Zacharatos, A., Barling, J. and Kelloway, E.K. (2000) Development \& effects of transformational leadership in adolescents. The Leadership Quarterly, 11: 211-226.

83. Zhu, W., Chew, I.K.H. and Spangler, W.D. (2005) CEO transformational leadership \& organizational outcomes: The mediating role of human-capital-enhancing human resource management. The Leadership Quarterly, 16(1): 39-52. 